\title{
NOONAN SYNDROME: A CLINICAL AND GENETIC STUDY OF 31 PATIENTS
}

\author{
Débora Romeo Bertola, Sofia M. M. Sugayama, Lilian Maria José Albano, \\ Chong Ae Kim and Claudette Hajaj Gonzalez
}

RHCFAP/2981

BERTOLA, D.R. et al. - Noonan syndrome: a clinical and genetic study of 31 patients. Rev. Hosp.Clin. Fac. Med. S. Paulo 54 (5):147-150,1999.

SUMMARY: Noonan syndrome is a multiple congenital anomaly syndrome, inherited in an autosomal dominant pattern. We studied 31 patients (18 males and 13 females) affected by this disorder regarding their clinical and genetic characteristics. The most frequent clinical findings were short stature (71\%); craniofacial dysmorphisms, especially hypertelorism, ptosis, downslanting of the palpebral fissures; short or webbed neck (87\%); cardiac anomalies $(65 \%)$, and fetal pads in fingers and toes $(70 \%)$. After studying the probands' first-degree relatives, we made the diagnosis of Noonan syndrome in more than one family member in three families. Therefore, the majority of our cases were sporadic.

DESCRIPTORS: Noonan syndrome. Valvar pulmonary stenosis. Autosomal dominant. Proband.

Noonan syndrome (NS), described in 1963 by Noonan and Ehmke', is characterized by short stature, dysmorphic craniofacial features, short or webbed neck, congenital heart disease, cryptorchidism in the males, skeletal anomalies and bleeding diathesis.

Its incidence is not well characterized, but is estimated at $1 / 1000$ to $1 / 2500^{2}$, which makes this disorder one of most common syndromes associated with congenital heart disease.

The majority of the cases are sporadic, but familial transmission has been well documented ${ }^{3,4}$, consistent with an autosomal dominant pattern of inheritance. There is a preponderance of maternal transmission, which is attributed to the cryptorchidism in the males and consequent infertility.

The gene responsible for NS was mapped to the long arm of chromosome $12^{5,6}$, but some families have no linkage to this region, indicating genetic heterogeneity in this disorder ${ }^{5}$.
We were interested in studying the clinical and genetic aspects of this syndrome due to its frequency and its wide phenotypic spectrum.

\section{METHODS}

We identified 31 patients affected by NS, derived from 26 families.

The ascertained proband and his first-degree relatives underwent a standardized questionnaire and physical examination. They were classified as affected by this disorder based on the clinical criteria described by van der Burgt et al. ${ }^{5}, 1994$. For those individuals classified as affected, a complete cardiac work-up, comprising EKG and echocardiogram, an abdominal ultrasound, column and wrist X-rays, ophthalmological examination, and coagu-

From the Genetics Clinic Unit, Child Institute, University of São Paulo School of Medicine, São Paulo - Brazil. lation studies were performed. These latter consisted of a bleeding time (BT) by the Ivy method, a prothrombin time, an activated partial thromboplastin time, a thrombin time, a platelet count, and a coagulation assay for factor XI. If any of these studies yielded abnormal results, it was followed by a more extensive work-up. Karyotyping was done in all probands.

The patients were included in this study only after a written consent was obtained.

\section{RESULTS}

Thirty-one patients (18 males and 13 females) were included in this study. Their ages ranged from 3 months to 41 years (mean 12 years). Twelve probands $(46 \%)$ were white, 10 were mulatto (38\%), 3 were black (12\%), and 1 was oriental (4\%).

The mean age of the diagnosis in the probands was 6 years and 9 months. 


\section{PRENATAL AND BIRTH DATA}

Complications during pregnancy were observed in 11 gestations out of 30 (36\%); one patient was adopted and there was no record of that period. The most frequent complications were premature contractions and vaginal bleeding (20\%) and polyhydramnios $(10 \%)$.

The majority of the patients were born at term $(90 \%)$, by cesarean section $(50 \%)$.

Birth weight was known in 27 babies born at term, with a mean of $3365 \mathrm{~g}$ for the females and $3445 \mathrm{~g}$ for the males. Length was known in 22 patients with a mean of $48.05 \mathrm{~cm}$ for the females and $48.5 \mathrm{~cm}$ for the males.

Some anomalies of NS, such as congenital heart defect and lymphedema were observed in $23 \%$ and $13 \%$ of the patients, respectively, in the neonatal period.

The stay in the nursery ranged from 1 to 30 days (mean 7 days).

\section{CLINICAL FINDINGS (Table 1)}

\section{CARDIAC FINDINGS}

Twenty patients $(65 \%)$ had congenital heart defects (Table 2).

A superior deviation of the QRS axis was frequently found in the EKG (52\%), not associated with a specific heart defect. Signs of right ventricular hypertrophy were present in 13 patients and left ventricular hypertrophy in 5 .

\section{HEMATOLOGICAL EVALUATION}

Six patients showed a tendency to bleed, usually mild, characterized by hematomas, epistaxes, and a prolonged bleeding time.

The coagulation assays in these patients revealed anomalies in nine of them (Table 3).

Table 1 - Clinical findings in 31 patients with NS.

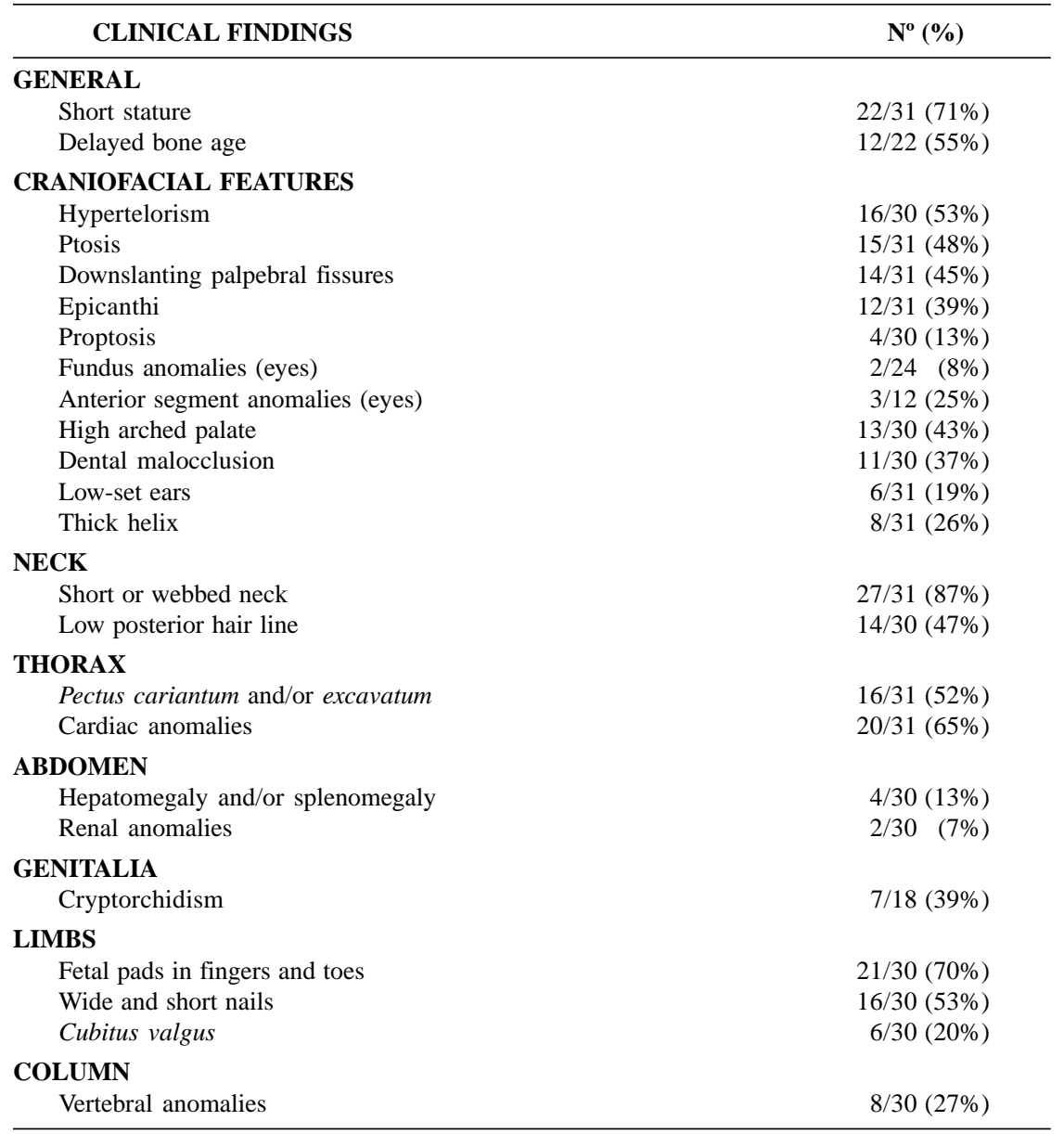

Table 2 - Congenital heart defects observed in 31 patients with NS.

\begin{tabular}{lc}
\hline \multicolumn{1}{c}{ CARDIAC ANOMALIES } & $\mathrm{N}(\%)$ \\
\hline - VPS and/or SVPS & $10 / 23(43 \%)$ \\
- VPS/ASD & $3 / 23(13 \%)$ \\
- VPS/MVP & $1 / 23(4 \%)$ \\
- VPS/HCM & $3 / 23(13 \%)$ \\
- HCM & $4 / 23(17 \%)$ \\
- VSD & $1 / 23(4 \%)$ \\
- Valvar aortic thickened & $1 / 23(4 \%)$
\end{tabular}

VPS and/or SVPS = Valvar pulmonary stenosis/supravalvar pulmonary stenosis

VPS/ASD = Valvar pulmonary stenosis/atrial septal defect

VPS/MVP = Valvar pulmonary stenosis/mitral valve prolapse

VPS/HCM = Valvar pulmonary stenosis/hypertrophic cardiomyopathy

$\mathrm{HCM} \quad=$ Hypertrophic cardiomyopathy

VSD $\quad=$ Ventricular septal defect

\section{GENETIC ASPECTS}

We examined all first-degree relatives of the probands, personally $(68 \%)$ or by photographs $(32 \%)$, except for two: one patient was adopted and the father of another child was not available. In the remaining 24 families, three $(12.5 \%)$ had more than one affected person. 
Table 3 - Hematologial findings in 31 patients with NS.

\begin{tabular}{lc}
\hline HEMATOLOGIAL FINDINGS & $\mathrm{N}^{\circ}(\%)$ \\
\hline - Thrombocytopenia & $2 / 10(20 \%)$ \\
- Deficient platelet aggregation & $1 / 10(10 \%)$ \\
- Increased BT & $1 / 10(10 \%)$ \\
- Isolated FXI deficiency & $1 / 10(10 \%)$ \\
- Combined FXI deficiency & $2 / 10(20 \%)$ \\
- Isolated FXII deficiency & $1 / 10(10 \%)$ \\
- Combined FXII deficiency & $1 / 10(10 \%)$ \\
\hline
\end{tabular}

Karyotype was normal in every proband.

\section{DISCUSSION}

NS is considered a frequent autosomal dominant disorder and its wide phenotypic spectrum led these patients to the attention of different clinicians, such as, endocrinologists, ophthalmologists, cardiologists, pediatricians, and hematologists. A better understanding of this heterogeneous syndrome allows a more accurate management of these patients.

Prenatal history is usually unremarkable, but sometimes polyhydramnios can be detected by fetal ultrasound. Sharland et al. (1992) ${ }^{7}$ observed this anomaly in 43 of 130 pregnancies of fetuses affected by NS. It was also observed in our study, but in just $10 \%$ of pregnancies, probably due to the lack of ultrasound performed in the mothers of our patients.

Short stature is proportional and post-natal. These patients have a normal birth weight and length. Their growth decreases by three months of age and remains consistently below the $5^{\text {th }}$ percentile. ${ }^{8}$ The bone age has usually a two-year delay. In our study, $71 \%$ of our patients were three SD below the mean for height, and 55\% of them showed a delayed bone age.

The most frequent craniofacial features observed in this study include hypertelorism, ptosis, downslanting of the palpebral fissures, high arched palate and dental malocclusion. Lee et al. ${ }^{9}$ (1992) found ocular anomalies in $95 \%$ of 58 patients with NS. The most common were hypertelorism, refractive errors, and anterior segment changes, especially prominent corneal nerves. This latter was diagnosed in three of our patients.

Cardiac abnormalities are common findings in NS, and they are the principal concern in this disorder. In our study, $65 \%$ of the patients had a congenital heart defect. This frequency is higher than the $50 \%$ estimated in this syndrome ${ }^{10}$, and it is probably due to the preferential referral of our patients from a cardiac clinic.

The most frequent heart defect observed in our study was pulmonary stenosis (PS), present in 17 patients out of 20 with cardiac anomalies $(85 \%)$. The prevalence of this heart defect in NS is well described in the literature ${ }^{7,11}$. It was an isolated finding in nine instances (53\%) and when associated with another cardiac anomaly, the most common were atrial septal defect (ASD) and hypertrophic cardiomyopathy (HCM) (three cases each).

The second most common cardiac anomaly in NS is the $\mathrm{HCM}^{7}$, also observed in our study. Unlike the nonsyndromic HCM, in NS it is frequently associated with a heart defect, especially PS ${ }^{12}$. Here, four out of our five patients with HCM had associated pulmonary, aortic, or tricuspid valves involved.

Other congenital heart defects observed in our study were a ventri- cular septal defect (VSD) and valvar aortic thickened in one patient each. Noonan ${ }^{13}$ (1994) stated that virtually every type of heart defect has been described in this disorder.

The EKG showed a superior deviation of the QRS axis in 16 patients $(80 \%)$, observed in cases with valvar pulmonary stenosis (VPS), supravalvar pulmonary stenosis (SVPS), HCM and VSD. Superior deviation of the QRS axis was not found in patients without cardiac anomalies. This finding is a helpful tool in the diagnosis of a NS patient ${ }^{14}$.

The cardiac involvement in these patients is a frequent finding and has peculiarities when compared to nonsyndromic heart anomalies. Also, these patients frequently have a chest deformity with pectus carinatum superiorly and excavatum inferiorly ${ }^{15}$, which interferes with cardiac auscultation. Therefore, a complete cardiac work-up should be performed in every patient with a suspected diagnosis of NS, with EKG and echocardiogram.

Genital anomalies are frequent in the males, especially the cryptorchidism, considered responsible for the infertility observed in this group of patients. Cryptorchidism was observed in seven $(39 \%)$ of our male patients and was bilateral in six of them.

Vertebral anomalies were discovered in $27 \%$ of our patients. They were not prominent clinically and were mainly spina bifida occulta, scoliosis, and kyphosis.

Hematological anomalies in NS involve platelets (number and function) and coagulation factors, especially factor XI deficiency ${ }^{16}$. In our study, factor XI deficiency was also the most common, isolated or associated with other deficient factors, such as, factor XII, VIII, IX, and ristocetin cofactor. There was a poor correlation between the bleeding history and the coagulation assays findings ${ }^{16}$. In our study, nine patients had anomalies in the 
coagulation assays, but only two of them had a history of bleeding.

NS is both clinically and genetically complex. It is considered an autosomal dominant disorder with variable expression and incomplete penetrance. Molecular studies have confirmed that it is a heterogeneous disorder.
In our study, the majority of the cases were sporadic. Familial instances were observed in only three families. The characterization of familial and sporadic cases is essential for adequate genetic counseling, requiring a careful physical examination of all first-degree relatives ${ }^{17}$. The recurrence risk for the children of an affected person is $50 \%$ and is less than $1 \%$ for normal parents of a child affected by this disorder.

The identification of a marker, by molecular techniques, would help in the diagnosis and genetic counseling of a NS patient. At present, diagnosis relies primarily on clinical observations.
BERTOLA, D.R. e col. - Síndrome de Noonan: um estudo clínico e genético de 31 pacientes. Rev. Hosp. Clín. Fac. Med. S. Paulo 54 (5): 147-150,1999.

A síndrome de Noonan é uma patologia de múltiplas anomalias congênitas, herdada em um padrão de herança autossômico dominante. Estudamos 31 pacientes (18 do sexo mas- culino e 13 do sexo feminino) afetados por essa síndrome quanto aos aspectos clínicos e genéticos. As características clínicas mais frequientemente observadas foram a baixa estatura $(71 \%)$; os dismorfismos craniofaciais, principalmente o hipertelorismo, a ptose e a inclinação ínfero-lateral das fendas palpebrais; o pescoço curto ou alado $(87 \%)$; as anomalias cardíacas $(65 \%)$ e a presença de coxins nas pontas dos dedos das mãos e pés (70\%). Após estudarmos os parentes de primeiro grau dos probandos, fizemos o diagnóstico da Síndrome de Noonan em um deles em três famílias. Portanto, a maioria dos nossos casos foram esporádicos.

DESCRITORES: Síndrome de Noonan. Estenose pulmonar valvar. Autossômica dominante. Probando.

\section{REFERENCES}

1. NOONAN JA \& EHMKE DA - Associated noncardiac malformations in children with congenital heart disease. J Pediatr 1963; 63: 468470.

2. NORA JJ, NORA AH, SINHA AK, et al. - The Ullrich-Noonan syndrome (Turner phenotype). Am J Dis Child 1974; 127: 48-55.

3. NORA JJ \& SINHA AK - Direct male to male transmission of the XY Turner phenotype. Lancet 1970; 1: 250.

4. LEVY EP, PASHAYAN H, FRASER FC et al. - XX and XY Turner phenotypes in a family. Am J Dis Child 1970; 120: 36-43.

5. JAMIESON CR, VAN DER BURGT I, BRADY AF et al. - Mapping a gene for Noonan syndrome to the long arm of chromosome 12. Nature Genet 1994; 8: 357-360.

6. LEGIUS E, SCHOLLEN E, MATTHIJS G et al. - Fine mapping of Noonan/cardio-facio cutaneous syndrome in a large family. Eur J Hum Genet 1998; 6: 32-37.

7. SHARLAND M, BURCH M, MCKENNA WM et al. - A clinical study of Noonan syndrome. Arch Dis Child 1992; 67: 178-183.

8. WITT DR, KEENA BA, HALL JG et al. - Growth curves for height in Noonan syndrome. Clin Genet 1986; 30: 150-153.

9. LEE NB, KELLY L \& SHARLAND KM - Ocular manifestations of Noonan syndrome. Eye 1992; 6: 328-334.
10. MENDEZ HMM \& OPITZ JM - Noonan Syndrome: a review. Am J Med Genet 1985; 21: 493-506.

11. NOONAN J \& O'CONNOR W - Noonan syndrome: a clinical description emphasizing the cardiac findings. Acta Pediatr Jpn 1996; 38: 76-83.

12. NISHIKAWA T, ISHIYAMA S, SHIMOJO T, et al. Hypertrophic cardiomyopathy in Noonan syndrome. Acta Pediatr Jpn 1996; 38: $91-98$.

13. NOONAN JA - Noonan syndrome. An update and review for the primary pediatrician. Clin Pediatr 1994; 33: 548-555.

14. NOONAN JA - Hypertelorism with Turner phenotype. A new syndrome with associated congenital heart disease. Am J Dis Child 1968; 116: $373-380$

15. ALLANSON JE - Noonan syndrome. J Med Genet 1987; 24: 9-13.

16. SHARLAND M, PATTON MA, TALBOT S et al. - Coagulation-factor deficiencies and abnormal bleeding in Noonan's syndrome. Lancet 1992; 339: 19-21.

17. SHARLAND M, MORGAN M, SMITH G et al. - Genetic counselling in Noonan syndrome. Am J Med Genet 1993; 45: 437-440.

Received for publication on the 12/08/99 